\title{
Parasocial Relationships and the Formation of Hyperreality in the BTS World Game
}

\author{
Jasmine Alya Pramesthi \\ Pascasarjana Departemen Ilmu Komunikasi, Universitas Indonesia, Jl. Salemba Raya, Jakarta, Indonesia. \\ E-mail: jasmine.alya@ui.ac.id
}

\begin{abstract}
The rapid development in the gaming business makes games, besides being a means of entertainment, also become the promotional tools for companies. One of them is the BTS World game released by Big Hit Entertainment to promote the K-Pop idol group, BTS. From the fandom perspective as the game users, BTS World is a form of media artifact facilitated by the company. BTS World is a video game as an adaptation of fan fiction, in which most of the story contents are the interaction between users and BTS members as the characters of the game. From the contents, it is possible to create a parasocial relationship and hyperreality felt by its players. The researcher conducted a study using a qualitative approach and phenomenological method to describe the meaning of the BTS World game and the experiences felt by the players both in parasocial relationships and forming hyperreality. Based on the results, the parasocial relationship, the meaning between parasocial friendship and parasocial, and the formation of hyperreality were found, which leads to the meaning of pseudo interaction and control of the characters' life.
\end{abstract}

Keywords: video game, parasocial, hyperreality, BTS World

\section{INTRODUCTION}

The development of communication technology has made the exchange of information between humans more quickly, effectively, and efficiently. Communication technology has a role that cannot be separated from modern human life. Even almost all aspects of human life have an offense with the presence of technology. In recent years humans have been faced with changes in the digital world that have affected many individuals because digital systems have become an essential factor in their daily activities. This makes the use of smartphones to be the daily needs.

People often use a smartphone for various purposes in everyday life. The reason is, smartphone currently provides various facilities that owners or users can use to access various things (Satriani \& Rinawati, 2020). Products created from technological developments can be found every day, one of which is in the form of entertainment through video games. A video game is a game played with an audio-visual device and can be based on a story (Esposito, 2005). One of the things that makes video game popular is that it is designed very attractively to amaze and arouse the players' curiosity. To amaze the players, a video game usually presents exciting gameplay with realistic images and sounds. A virtual world in the video game is created with the inspiration of real-life locations. This is intended to provide a sensation as if the player is visiting the actual location not 
to be easily bored. In addition, the game also makes players familiar and easy to measure the area (Eskasasnanda, 2017).

The rapid development in the gaming business makes games, besides being an entertainment tool, also become a promotional tool for brands to use a game as a branding platform. Suppose an organization or company ignores the development of games. In that case, the company will face the same fate as those organizations and companies that ignore the rise of the internet as a promotion media. The absence of careful strategic planning will make the company or organization lag behind the competitors that are sensitive in seeing the increasing number of game users so that game is used as a promotion media. This is also following organizations and companies that ignore promotion through the internet. One of the commonly known cases is the competition between Netflix and Blockbuster. Netflix, which has innovation by utilizing the internet, left Blockbuster behind until it finally went bankrupt.

In playing a viral promotion game, players can experience virtually the brand they want to share (Renard \& Darpy, 2017). A game has a role in marketing as a promotional tool. One form of promotion using games is utilized by one of the entertainment companies to promote their artists, especially in the K-Pop industry. The media synergy is commonly found in K-Pop. K-Pop entertainment companies are known for producing merchandise, one of which is games. This trend was started by the SM Entertainment company in 2014 when they released Superstar SMTOWN. Various games such as Superstar SMTOWN, Superstar BTS, Superstar JYP, and BTS World are examples of how the gaming and K-Pop industries rely on each other (Aastha, 2019).

As a promotional tool for artists from the perspective of the users, which is a fandom, a video game is a form of media artifact facilitated by the company. Media artifact is one form of fan activity with various forms (Long \& Wall, 2012). The utilization of a video game as a form of artifact for fandom is a video game released by Big Hit Entertainment in collaboration with Netmarble Corp. \& Takeone Company, namely BTS World.

BTS World is a video game, which is an adaptation of fan fiction, in which most of the story content is the interaction between the users and BTS members as the characters in the game. This video game was released in 2019. The synopsis in the video game tells the users as the manager who manages the South Korean boy band BTS. After winning the ticket to see the concert, the users are brought back from 2019 to 2012, the year before the group was released debuted. From there, the users find that the users not only travel to the past, but the users are also the employee of Big Hit Entertainment, the BTS company, and are responsible
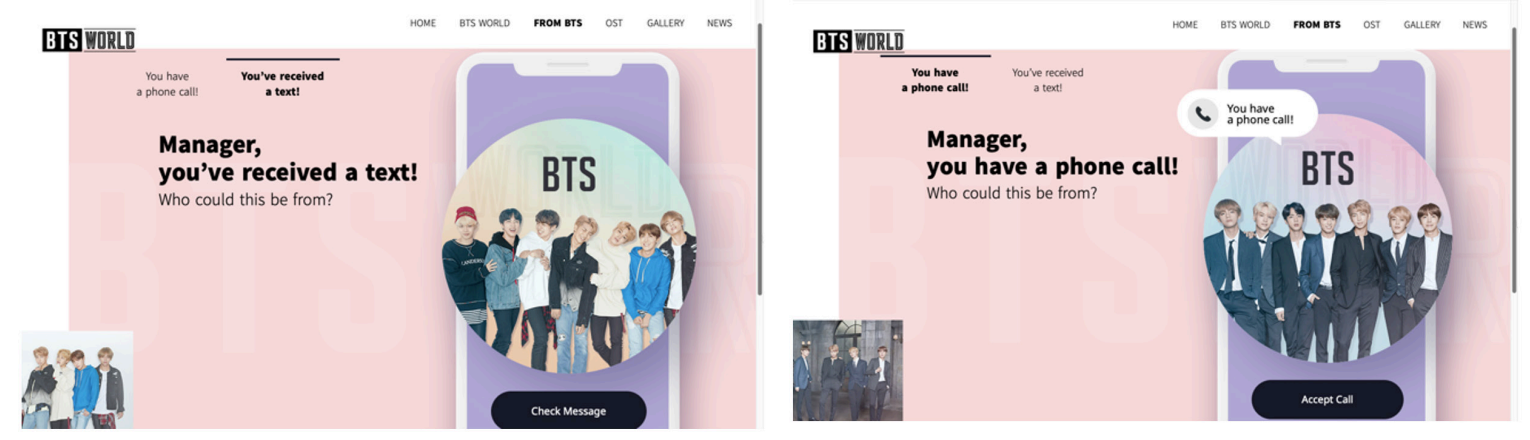

FIGURE 1. The View of the BTS World Website 
for bringing the group together (Haasch, 2019). The video game presents contents that seem to bring the users to interact directly with BTS members, either through phone calls or short messages, as in the FIGURE 1.

The following is a screenshot from the official website of the BTS World video game, which explains that users who act as managers of BTS will get short messages from BTS. Besides short messages, users also seem to get phone calls from BTS members.

BTS or Bangtan Sonyeondan in Korean or Beyond the Scene in English is a boy band group from South Korea founded on June 13, 2013. BTS has won an award from Billboard with the Top Social Artist category in a row since 2017. According to Billboard, winners are selected based on the main fan interactions with music, including album sales and digital song, streaming, radio playback, tours, social engagement, and the results of global online voting by fans (Herman, 2018). Thus, it can be stated that BTS has a solid fan base called ARMY.

On July 13, 2013, ARMY was formed one month after BTS officially debuted as a boy band group. Several studies discussed the relationship between idols and fans, which is explained as a parasocial relationship. The concept of parasocial is a popular concept among those who study the media effects and media. Initially suggested by Horton and Wohl (1956), parasocial refers to the reaction of media users to media actors so that media users assume the actors as an intimate conversation partner (Dibble et al., 2015).

Mihardja \& Paramita (2019) explained in their study that there is a parasocial between ARMY and BTS, especially in fangirls, there is an emotionally intense relationship. Therefore, it forms an impulsive response to whatever BTS was doing, and there is an interest in building a relationship that was more than just a fan with BTS. Fans who are members of fandom are identically wearing attributes about their favorite idol (Afifah \& Kusuma, 2019), and there is a desire to be recognized as a faithful fan (Ruthllianie \& Candraningrum, 2020).

Based on the following explanation, as a parasocial, fans assume that they have a close relationship with their idol to create a parasocial relationship. This can also be explained in the concept of hyperreality by Jean Baudrillard, which was present due to the development of technology and the economy of postmodern societies that consume signs but are full of meaning. Simulation, which represents a reality, experiences duplication of reality, namely simulacrum, so that the difference between authenticity and simplicity cannot be found, referred to as hyperreality (Diah Natalia et al., 2019).

The creation of pseudo-reality or hyperreality in the fandom world is considered to be formed from available media artifacts. In the implication of the BTS World video game, where the users are positioned as the manager who manages the BTS, it assumes that the users are a part of BTS's life, which is supported by the existence of a simulacrum space.

There are several previous studies regarding both parasocial and hyperreality perceived by fans separately. Parasocial, explained by Rasmussen (2018), is that respondents report a feeling of knowing and familiarity with the speakers, thereby revealing parasocial occurrence. Audiences socialize with YouTube celebrities, who may also serve as brand ambassadors. In a particular meaning, YouTube Celebrities become their friends to share opinions.

Moreover, Rachman et al. (2020) explained that hyperreality means creating a new reality that does not follow reality itself. This is based on research 
regarding the action of K-Pop fans in Malang. Many fans claim to be lovers of their idols and think their idols are near them, but they are not. Furthermore, a study concerning hyperreality in a game was explained by Tuela \& Susilo (2017) that the phenomenon of hyperreality in the Pokemon Go game is a place where the game players feel they are in their world and their activities in the game world so that the meanings, symbols, and codes are no longer valid.

Unlike the previous studies, the researcher would like to research by combining two concepts, parasocial relationships, and hyperreality as the theme of the study in the BTS World game phenomenon. The researcher chose this phenomenon because of the parasocial relationship between ARMY and BTS, which is later elaborated on how the BTS World game creates hyperreality for ARMY.

\section{METHOD}

The researcher conducted a study using a qualitative approach and a constructivist paradigm. The constructivist paradigm from an interpretive perspective that the reality is not something "out there" that can be explained, described or interpreted clearly by the researcher into a research report. On the other hand, either reality or knowledge is constructed and reproduced through communication, interaction, and practice (Tracy, 2020). Whereas the study method was a phenomenological method to describe the meaning of the BTS World game and the experiences felt by BTS World game players both in terms of social relationships and forming hyperreality. To describe the meaning of parasocial meaning and hyperreality, the researcher arranged the category of meaning as a second construct degree.

Afterward, to get the study's data, the researcher chose five informants considered to be involved either as BTS World game players or the ARMY fandom with the criteria determined by the researcher. The criteria of informants are that they have joined the ARMY fandom for at least one year and actively become the BTS World game player. The information obtained from in-depth interviews was selected based on the purposive sampling technique, which has the basis for obtaining all possible cases according to specific criteria using various methods (Djamba \& Neuman, 2014).

The data obtained from in-depth interviews were primary data that are then complemented by various secondary data, including literature reviews in the form of books, previous studies, or data obtained from the internet.

\section{RESULT AND DISCUSSION Parasocial Relationship}

In a parasocial relationship, fans have an assumption that they are close to their idol, and this closeness feels like an interpersonal relationship for fans. Nevertheless, in reality, this interpersonal closeness is only felt by one side, the side of the fans (Sagita \& Kadewandana, 2018). Interpersonal closeness in the parasocial relationship involves emotions from fans, as explained by Weaver (1993). The factors of emotional involvement are based on the repeated interaction, high self-disclosure, high interdependence, and high emotional involvement.

\section{Repeated Interaction}

In repeated interaction, fans, especially BTS World players, regularly access the game. Not only limited to game access, but players also periodically find out the latest information about the BTS World game through BTS World social media and are active in the forums provided in the game.

Based on the information obtained from the five informants, all informants 
routinely open applications from BTS World. Two informants open the game twice a day at the same time every day, two informants open the game more than twice a day, and one informant opens the game every day but did not have a fixed number. The five informants followed the Twitter account of BTS World, and three of the informants actively joined the forums provided in the game. To maintain their interaction in the game, the five informants activate the notification feature in the game to stay connected when there is a new notification regarding the game.

The informants gave various reasons regarding the frequency of opening the BTS World application. Two informants explained that they routinely open the application at $12 \mathrm{pm}$ and $6 \mathrm{pm}$ due to the bonus given in the game if users access the game every 12 $\mathrm{pm}$ and $6 \mathrm{pm}$. One informant explained that although she/he does not have a fixed time to open the BTS World application, he/she opens the application every day. Meanwhile, the following two informants explained that they routinely interact with other BTS World game players through the forum features provided in the game, as described in the following interview quotation:

"At 12 pm and 6 pm, I will definitely open the game because it becomes a habit so that I always have (to open the game) at that time. However, I also open every 1-4 hours because every 1 hour, I can refresh (feature) the agency, then every 4 hours, I can upgrade items at the magic shop. I also often open (feature) posts, also follow (leave) comments, sometimes there are tips from other (players)" (Interview with Amel, January 23, 2021).

\section{High Self-Disclosure}

Besides the repeated interaction, the users of the BTS World game do not hesitate to make high self-disclosure as a BTS World game player to their surrounding environment. Game players express their feelings both through the forum feature in BTS World and through their respective social media.

As explained in the introduction that this game offers as if one becomes a manager, the five informants once consciously expressed the pride felt as a BTS manager. This is done by sending posts on social media about the achievements in the game achieved and uploading if they have succeeded in reaching a higher level. However, due to the law regulated in the game that players are prohibited from uploading in-app content, then the five informants follow the rules.

"Yeah, I also often upload it when I have just completed one level or get a new card on my Twitter. However, if, for example, I successfully unlock the video or I get the message content, I did not upload it. I just showed it off to people who were close to me. Like at that time, I showed off when I was invited to watch a movie with Jimin, hahaha" (Interview with Tari, January 22, 2021).

\section{High Interdependence}

BTS World game players also feel a high dependence on continuously accessing the BTS World game. This dependence is related to repeated interaction, in which when BTS World game players have to open the BTS World application every day by activating notifications from the game. Out of the five informants, all informants agreed that by accessing the game every day, they would get benefits and already considered the BTS World game as a daily routine 
that could not be missed even though the game requires ample memory storage for its users. They do not hesitate to make additional transactions to get easiness for informants to play the game.

"I always save my pocket money for VIP member subscriptions, only 75 thousand a month, but I can get additional ammunition, even my level has quickly increased because I am a VIP member subscription" (Interview with Tari, January 22, 2021).

This shows the dependence felt by game users. Even the informants do not hesitate to save their expenses from facilitating their activities in playing the BTS World game. Besides that, other informants also support the statement regarding the high dependence in the BTS World game as follows:

"From the first time the game was released, it means it has been more than a year; I rarely skip the game, never even. I always open it every day. It is because every noon, there is a check-in reward which is very useful so that my account level goes up. Moreover, every two weeks, there are new events in the game, so I am not bored playing it" (Interview with Dinda, January 22, 2021).

Unlike Dinda, Sheila downloaded the BTS World application not on her cellphone but through her tablet. There are times when the informant has left the house for days without his tablet so that the informant does not have the chance to open the BTS World application.

"There was one time when I was camping. Because there is no signal on the mountain and it will be heavy to bring an iPad, so I left it at home. I do not feel comfortable either because it is a habit, thinking it for two days I do not get (checkin) the reward " (Interview with Sheila, January 22, 2021).

\section{High Emotional Involvement}

Furthermore, there is high emotional involvement by users of the BTS World game. Various emotions occur when the user plays the game. These emotions are described as happy emotions generated when a user gets a new card, gets new content from the game in the form of videos, messages, and even received phone calls. Not only positive emotions, but users also feel annoyed when they have not succeeded in completing a mission or limited resources in the game. This shows that there is a high emotional involvement between BTS World game players.

"I have been successfully finished up Jungkook's chapter in a day, and I was glad because I could unlock Jungkook's exclusive video. I was thrilled, so I keep playing (the video). Seeing Jungkook taekwondo is very cool, and it was kind of a mood booster for me. Especially when I successfully unlock a video call with a member, it felt like I was that close to them" (Interview with Amel, January 23, 2021).

Besides happiness, informants often feel irritated emotions when they are playing the BTS World game.

"Yeah, sometimes it got irritated when I tried to complete one mission, but my card was not strong enough to finish the mission, even though the card I used was the highest (value). I wanted to draw a new card again, but my diamonds 
lack, and I wanted to buy diamonds, but I did not have any money "(Interview with Devy, January 23, 2021).

The results of the findings, the following study explained that there are meanings of parasocial perceived by informants as BTS World players, the meaning of parasocial friendship, and the meaning of parasocial love as defined by Tukachinsky (2010).

\section{Parasocial Friendship}

Parasocial friendship is described as a feeling of attraction with public figures, feeling the solidarity built, a trust formed, wanting two-way communication that leads to openness between the two. In this study, it can be understood that informants have a parasocial meaning of friendship with BTS members.

Personally, the informants feel that with repeated interaction, such as routinely opening applications, solidarity was formed between the informants and BTS members. Solidarity is also supported by the consistency of players in accessing the game at certain times so that players can get the benefit. Not only limited to game check-in time, but a meaning of solidarity is also built from the purchase of VIP features so that players can have more access than other users.

A feature that seems to put the game players on a video call is two-way communication, which the BTS World players wanted from the BTS members. Players' confidence is also formed from the availability of players in making transactions in the game. BTS World players do not hesitate to express their feelings in playing the BTS World game. The self-disclosure performed by the players shows the player's confidence in BTS. In-game features such as voice calls, video calls, text messaging, and status updates seem to show that the BTS members and the players (described as BTS managers) have an open relationship. However, all the parasocial meanings received by the players only run one way because all the responses by BTS members are the settings of the game system itself.

The motive underlying ARMY to be BTS World players to the formation of parasocial is due to the solidarity feeling of ARMY to support all activities carried out by BTS, including launching games considered to entertain ARMY. Besides that, as an entertainment company that houses BTS, Big Hit is considered facilitating the parasocial felt by ARMY through the BTS World game.

\section{Parasocial Love}

Unlike parasocial friendship, in parasocial love, there is a firm intention from BTS World players for the presence of BTS members, feeling a longing to be physically close, and there is an openness around to be accepted and noticed. In this study, it can be understood that informants have a meaning of parasocial love with BTS members.

Physical attraction towards BTS members leads to the firm intention of BTS World players for BTS members. The visual of each BTS member becomes a commodity to attract the loyalty of BTS World players. It can be seen from the content collection feature in the form of a new card displaying the photos of each BTS member. High emotional involvement shows the strong desire of BTS World players to be in parasocial relationships. Happy emotion is when successfully opening the latest content as if interact directly with BTS members, and irritated emotion is when can not complete the mission so they can not access the video call, voice call, and so on.

The habit of BTS World players causes a feeling of dependence. The 
informants mentioned that they once left home without playing BTS World, then they felt uncomfortable. Based on the findings of the study above, it can be stated that ARMY as BTS World players have a meaningful relationship with BTS members, both parasocial friendship and parasocial love.

\section{Hyperreality}

Hyperreality or pseudo-reality is a reality generated and the reproduction of objects with unreal object references (Dermartoto, 2009). The condition of reality creation outside the reality is called hyperreality (Wulandari \& Luthfi, 2018). At the level of consciousness, simulation kills the people's consciousness in actual reality. The logic applied in the simulation has nothing to do with the logic of real reality. The consciousness formed by pseudo-reality is a consciousness of simulated form. In the simulation era, the meaning of the world is based on pseudoreality in the form of images produced by various information media. After that, the definition of reality shifts to something that can be reproduced equally. An illusion is no longer a dream or a fantasy but an artificial illusion of reality itself. Information media has a role as a model for building values, self-image, and meaning in social life (Dermartoto, 2009). It is in accordance with the statement of the five informants that the informants felt as if the illusion was real, as explained below:

"Big Hit (the agency of BTS) is really good at making me hallucinated. I really feel very close to Bangtan, especially when they have a video call, send voice notes, duh" (Interview with Devy, January 23, 2021).

Through the informant data, according to the explanation from Dermartoto (2009), the existence of the simulation process kills the consciousness of BTS World game players regarding the reality that there is only a parasocial relationship felt by BTS World game players. The players feel pseudo reality through the BTS World game. This reality is reproduced equally by application developers, even though the logic applied in the simulation in the BTS World game has nothing to do with the logic of reality actually happened. Logic in reality that places game players only as application users is shifted by the logic provided in the game, which is how game players place themselves as managers of BTS and have closeness with BTS members.

Baudrillard's focal point lies in the influence of technological advances in the process of reproducing objects in contemporary society, especially in Western culture by what they call simulation. The simulation generates a separate space known as the simulacrum space. Simulacrum space is a space containing pseudo realities (hyperreality). Baudrillard emphasized that the purpose of the simulation is to simulate the diffusion process of forming an object, an object based on an incorrect reference source (Dermartoto, 2009). Regarding the relationship between the simulation world and hyperreality, Baudrillard saw that in the real model, making an unreal thing becomes real through a simulation mechanism (Andreas, 2020).

Game with virtual simulation basis builds the implementation of simulacra and simulation concepts. The process of forming hyperreality illustrated in the BTS World game is the simulation performed by the game developer, which ensures the consciousness of BTS World players with real reality that everything that happened is only the settings of the game. The logic applied in the game has nothing to do with real reality. There is a fictional arrangement that the fate of BTS members depends on how the players 
direct their game. Game players who have a role as manager of BTS have the right design their members, from the clothes that will be worn to the activities that will be done. Furthermore, through another alternative mode, the "Another Story" chapter, the game developer provides a simulation process to the players to enter the pseudo-reality if the BTS members are not K-Pop idols.

The findings explain that there are two meanings of hyperreality felt by informants as BTS World players, the meaning of pseudo-social interaction and the meaning to determine the life of a character.

\section{Pseudo Social Interaction}

When discussing hyperreality, a person's paralysis is not felt by a person, or there is a pseudo-reality. In the information conveyed by the informants, it was stated that the existence of the BTS World game makes players feel the interaction between them and BTS members through the facilities and content provided in the game. The video call and voice call contents seem to put the position of information in a twoway interaction with BTS members. The text messaging content with the answer choices makes the players do not feel one-way communication. The meaning created by BTS World game players is undoubtedly far from the actual logic that happened. The personalization set in the game makes players feel special, but the content is designed for millions of players.

\section{The Control of Character Life}

The game contents that have been set in the game show the structural and systematic characteristics, but it is packaged as if players can determine BTS members' lives as the character in the game. If faced with a situation, the players were provided an alternative to determining the fate of the game characters, which are the BTS members. All alternative chosen by the players will lead how the BTS act in the future at the game.

This is a specialization created to build hyperreality in the BTS World game. The simulation process places as if the BTS World players can determine BTS members' lives as a manager, but it actually has been set from the beginning by the developer. The life of BTS members, either in appearance, performance, or levels as an idol, is determined by the BTS World players that have a position as a manager.

In the K-Pop industry, fan service is often carried out by the entertainment agency, one of which is by giving extra detail to the game released to create the pseudo consciousness as if there is an interaction and life of idol set by the fans.

\section{CONCLUSION}

To explain how parasocial relationships and the formation of hyperreality occur in BTS World gamers, researchers conducted a study on five BTS World gamers as informants. The following study answers the research question that parasocial relationships and the meaning of parasocial friendship and parasocial love and the formation of hyperreality lead to the meaning of pseudo-interaction and control of the character's life.

The following research contributes novelty to enrich the study of parasocial relationship studies that are elaborated with the concept of hyperreality, where the majority in the study of celebrities are limited to parasocial relationships, have not been elaborated with the concept of hyperreality, so it can be explained that with the formation of parasocial relationships, it can not be separated from the existence of hyperreality. The findings in this study also explain that 
parasocial relationships can be formed through online games. The lack of studies that discuss it, parasocial studies are widely discussed through social media or through entertainment media such as movies.

The researcher arranges a suggestion for the further researcher to conduct a study using other theories, such as the social construction of reality, to enrich the scientific knowledge of communication from different perspectives. Based on the emotional factors in a parasocial relationship, the researcher suggests that other game developers be able to involve the users' emotion as the main focus in developing a game application to create a loyal consumer behavior.

\section{REFERENCES}

Aastha. (2019). How South Korea's K-Pop and Gaming Industries are Boosting Each Other. https://seoulbeats. com/2019/01/how-south-koreas$\mathrm{k}$-pop-and-gaming-industries-areboosting-each-other/

Afifah, E. O., \& Kusuma, T. (2019). Analisis Komunikasi Antar Penggemar Seventeen Sebagai Cyberfandom Di Twitter. Mediator: Jurnal Komunikasi, 12(1), 71-80. https://doi.org/10.29313/mediator. v12i1.4624

Andreas, R. (2020). Analisis Hiperrealitas dalam Film Spiderman: Far from Home ( 2019 ). 2019, 31-38.

Dermartoto, A. (2009). Membahas Gagasan Post Modernisme Baudrillard : Realitas Semu. Jurnal Sosiologi Dilema, 21(2).

Diah Natalia, N. K. A., Sugiarica Joni, I. D. A., \& Purnawan, N. L. R. (2019). Hiperrealitas Media Sosial Dalam Film Black Mirror Episode Nosedive. E-Jurnal Medium, 1(2).

Dibble, J. L., Hartmann, T., \& Rosaen, S. F. (2015). Parasocial Interaction and Parasocial Relationship: Conceptual Clarification and a Critical Assessment of Measures. Human Communication Research, 42(1),
21-44. https://doi.org/10.1111/ hcre. 12063

Djamba, Y. K., \& Neuman, W. L. (2014). Social Research Methods: Qualitative and Quantitative Approaches. In Pearson Education Limited. https:// doi.org/10.2307/3211488

Eskasasnanda, I. D. P. (2017). Causes and Effects of Online Video Game Playing among Junior-Senior High School Students in Malang East Java. KOMUNITAS: International Journal of Indonesian Society and Culture, 9(2), 191-202. https://doi. org/10.15294/komunitas.v9i2.9565

Esposito, N. (2005). A short and simple definition of what a videogame is. Proceedings of DiGRA 2005 Conference: Changing Views Worlds in Play, January 2005.

Haasch, P. (2019). BTS World is straight up self-insert fanfiction. https://www. polygon.com/2019/6/27/18761650/ bts-world-mobile-game-app-reviewimpressions-fanfiction-pronouns

Herman, T. (2018). How BTS Took Over the World: A Timeline of The Group's Biggest Career Moments. https:/www.billboard.com/articles/ columns/k-town/8455612/btstakeover-timeline-bbmas

Long, P., \& Wall, T. (2012). Media Studies: Texts, Production, Context. Taylor \& Francais. http://library1.nida.ac.th/ termpaper6/sd/2554/19755.pdf

Mihardja, J., \& Paramita, S. (2019). Makna Idola Dalam Pandangan Penggemar (Studi Komparasi Interaksi Parasosial Fanboy dan Fangirl ARMY Terhadap BTS). Koneksi, 2(2), 393. https://doi. org $/ 10.24912 / \mathrm{kn} . v 2 \mathrm{i} 2.3915$

Rachman, N. Y., Jannah, N. F., Revilda, E., Nasihuddin, A., Wahdaniah, I., \& Fibrianto, A. S. (2020). Malang's K-Pop Fans Hyperreality. International Conference on Social Studies and Environmental Issues (ICOSSEI 2019), 404, 325-330. https://doi.org/10.2991/ assehr.k.200214.059

Rasmussen, L. (2018). Parasocial Interaction in the Digital Age: An Examination of Relationship Building and 
Jasmine Alya Pramesthi. Parasocial Relationships and the Formation of...

the Effectiveness of YouTube Celebrities. The Journal of Social Media in Society Spring, 7(1), 280 294. www.youtube.com

Renard, D., \& Darpy, D. (2017). Viral Promotional Games: Comparing the Impact of Player Skills Versus Incentive Rewards on Game Recommendation. Journal of Advertising Research, 57(2), 173181. https://doi.org/10.2501/JAR2017-024

Ruthllianie, J., \& Candraningrum, D. A. (2020). Studi tentang Motivasi ARMY Jakarta dalam Membeli Merchandise Idola (Studi Kasus Kaos Uniqlo X BT21). Prologia, 4(1). https://doi.org/10.24912/ pr.v4i1.6449

Sagita, A., \& Kadewandana, D. (2018). Hubungan Parasosial di Media Sosial (Studi pada Fandom Army di Twitter). CoverAge: Journal of Strategic Communication, 8(1), 45-58. http://journal.univpancasila. ac.id/index.php/coverage/article/ view $/ 582$

Satriani, A., \& Rinawati, R. (2020). The Influence of Knowledge about
Korean Culture on Decision of Purchasing Korean Mobile phones. Mediator: Jurnal Komunikasi, 13(1), $1-10$.

Tracy, S. J. (2020). Qualitative Research Methods: Collecting Evidence, Crafting Analysis, Communicating Impact. John Wiley and Sons, Inc. http://library1.nida.ac.th/ termpaper6/sd/2554/19755.pdf

Tuela, M., \& Susilo, D. (2017). Hyperreality: Pemaknaan dalam Penggunaan Game Pokemon Go. Jurnal Kajian Media, 1(1), 1-15. https://doi.org/10.25139/ jkm.v1i1.155

Tukachinsky, R. (2010). Para-Romantic Love and Para-Friendships: Development and Assessment of a Multiple Parasocial Relationship Scale. American Journal of Media Psychology.

Weaver, R. L. (1993). Understanding Interpersonal Communication. Library of Congress Cataloging in Publication Data.

Wulandari, S. S., \& Luthfi, A. (2018). Hiperealitas Kampung Pelangi Semarang. Solidarity, 7(2). 